\title{
$\cos =-830942-29$
}

Br ecceptence of this articts, the

publituher or recipiens seknowieden

the U.S. Government's right io

tho U.s. Coverno

retain a nonoxclusuve, royal ty. froa

liconis in and to eny coricte.

CONF-330942--29

DE84 000338

MASS TRANSFER BEHAVIOR OF A MODIFIED AUSTENITIC STAINLESS STEEL IN LITHIUH*

P. F. TORTORELLI and J. H. DeVAN

Metals and Ceramics Division, Oak Ridge National Laboratory, Oak Ridge, Tennessee 37830

An austenitic stainless steel that was developed to resist neutron damage was exposed to lithtum in the high-temperature part of a thermal convection loop for $6700 \mathrm{~h}$. Specimens of this Prime Candidate Alloy (PCA) composed of $65.0 \mathrm{Fe}-15.9 \mathrm{Ni}-13.0 \mathrm{Cr}-1.9 \mathrm{Mo}-1.9 \mathrm{Mn}-1.7 \mathrm{Si}-0.5 \mathrm{Ti}-0.05 \mathrm{C}$ (wt $\mathrm{x}$ ) were exposed at 600 and $570^{\circ} \mathrm{C}$ in woth solution annealed and cold worked forms. The dissolution process was found to be similar to other austenitic alloys in flowing lithium: weight losses of PCA eventually became linearly proportional to exposure time with the specimen surfaces exhibiting porous layers depleted in nickel and chromium. However, the measured weight losses and dissolution rates of these PCA specimens were higher than those of type 316 stainless steel exposed under similar conditions and can be attributed to the higher nickel concentration of the former alloy. The effect of cold work on dissolution rates was less definitive, particularly at $570^{\circ} \mathrm{C}$. At longer exposure times, the annealed PCA specimen exposed at $600^{\circ} \mathrm{C}$ suffered greater dissolution than the cold worked material, while no effect of prior deformation was observed by analysis of the respective surfaces.

\section{INTRODUCTION}

For fusion technology, the compatibility of possible structural alloys with the reactor coolant and the tritium-breeding material must be considered in the alloy development and reactor design efforts. In order to do this, corrosion studies of appropriate materials in possible fusion reactor environments are required. Since molten lithium can serve as an efficient coolant and/or tritium-breeding fluid for fusion reactors, it is important to determine if corrosion effects would limit the use of a particular alloy in nonisothermal lithium. This paper contains corrosion results from a thermal-convection loop experiment with a modified austenitic stainless steel (denoted Prime Candidate Alloy or P(A) that was primarily developed for improved resistance to neutron damage. 1 The purposes of this experiment were to investigate the corrosion of both solution-annealed and cold-worked PCA by flowing lithium and to compare the PCA results with data for standard annealed type 316 stainless steel to determine the effect of the difference between these two austenitic alloys on their corrosion behavior in lithium. Prior work with lithium loops has yielded baseline data for type 316 stainless steel exposed to thermally conventive lithium $2-4$ and has demonstrated the effect of nickel concentration on the corrosion of $\mathrm{Fe}-\mathrm{Ni}-\mathrm{Cr}$ alloys. 5,6 The only other results for PCA in lithium have come from a recent experiment in a forced convection loop. 7

\section{EXPERIMENTAL PROCEDURES}

The corrosion data were obtained using a lithium thermal convection loop (TCL) of the type previously described in detail.2,4 The lithium density gradient caused by the imposition of a temperature difference of $150^{\circ} \mathrm{C}$ $\left(600-450^{\circ} \mathrm{C}\right)$ across the loop resulted in a lithium velocity of approximately $30 \mathrm{~mm} / \mathrm{s}$. Such a slow rate would be characteristic of

*Research sponsored by the Office of Fusion Energy, U.S. Department of Energy unde ${ }^{*}$ contract W-7405-eng-26 with the Union Carbide Corporation.

MOTICE

PORTIONS OF THIS REPORT ARE ILLEGIBLE.

it has been reproduced from the best avallable copy to permit the broadest possible availability. 
lithium being used as a semistagnant tritium breeding fluid. The loop is designed to allow the coupons to be inserted and removed from the hot and cold legs without stopping the lithium flow. In this way, specimen weight and microstructural changes can be measured as a function of exposure time. In addition, the location of specimens in both the dissolution and deposition parts of the loop permits the measurement of any mass transfer tendencies. The TCL was constructed of type 316 stainiess steel and had circulated lithium for many thousands of hours prior to the insertion of the specimen set used in this study. The interior surface of the upper hot leg tubing was therefore depleted in nickel due to preferential leaching of this element. 3 The presence of the resultant ferritic surface may have an effect on the dissolution of the fresh austenitic loop coupons. However, this effect has been measured and has been taken into account when comparing the present dissolution data to prior results for type 316 stainless steel by using only data typical of such loop conditions.

The lithium used in the loop was purified by cold trapping and subsequent heating at $815^{\circ} \mathrm{C}$ for $100 \mathrm{~h}$ in a titanium-lined pot containing zirconium foil. Typical impurity concentrations of the purified lithium were 30 to $80 \mathrm{wt}$ ppm nitrogen and 30 to $130 \mathrm{wt}$ ppm oxygen.

The loop specimens were rectangular coupons measuring $-25 \times 8 \times 1 \mathrm{~mm}$. All the specimens in the cold leg and in most of those in hot leg locations were type 316 stainless steel while PCA coupons were placed at the hot test (600 and $570^{\circ} \mathrm{C}$ ) specimen positions. The compositions of these alloys are given in Table 1. Unlike the other spectmen locations, the PCA positions contained two coupons each (attached on opposite sides of the specimen rod). These sets of two coupons were composed of a PCA specimen that was 20-25\% cold worked (A3) and one that was cold worked then solution annealed at $1100^{\circ} \mathrm{C}$ for $30 \mathrm{~min}$ (Al).

Table 1. Compositions of PCA and type 316 stainiess stee]

\begin{tabular}{lcc}
\hline Element & $\begin{array}{c}\text { PCA } \\
\text { (Actual) }\end{array}$ & \begin{tabular}{c} 
Concentration, wt $\%$ \\
\cline { 2 - 2 } Type 316 stainless steel \\
(nominal)
\end{tabular} \\
\hline $\mathrm{Fe}$ & 65.0 & 67 \\
$\mathrm{Cr}$ & 13.0 & 17 \\
$\mathrm{Ni}$ & 15.9 & 11 \\
$\mathrm{Mo}$ & 1.9 & 2 \\
$\mathrm{Mn}$ & 1.9 & 2 \\
$\mathrm{Si}$ & 1.7 & 1 \\
$\mathrm{Ti}$ & 0.5 & \\
$\mathrm{Al}$ & 0.05 & 0.08 \\
$\mathrm{C}$ & 0.05 & 0 \\
\hline
\end{tabular}

The specimen weights were measured eight times during the $6700 \mathrm{~h}$ of coupon exposure to lithium in the TCL. At the end of this period, the PCA specimens were metallographically examined and selected surfaces were analyzed by scanning electron microscopy and associated energy dispersive $x$-ray analysis.

\section{RESULTS}

Weight change measurements of PCA as a function of time at the 600 and $570^{\circ} \mathrm{C}$ positions revealed that, at $600^{\circ} \mathrm{C}$, the cold-worked specimen (PCA-A3) initially had slightly higher weight losses than the annealed specimen (PCA-A1) but, at longer times ( $3000 \mathrm{~h})$, the latter material had significantly higher cumulative weight losses (Fig. 1). This figure also shows that both specimens suffered greater weight losses than annealed type 316 stainless steel exposed under similar conditions. The data for the PCA specimens at $570^{\circ} \mathrm{C}$ do not show similar tendencies; wile the cold-worked specimen initially had slightly greater weight losses than the annealed material, the overall weight losses are similar for the two at longer times. Furthermore, the weight loss data for 
PCA falls within the scatter band for type 316 stainless stee?.

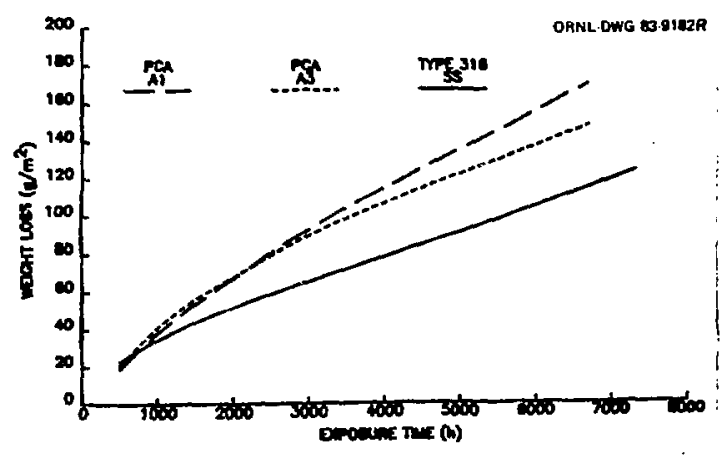

FIGURE I

Weight loss versus exposure time for PCA and type 316 stainless steel exposed to thermally convective lithium at $600^{\circ} \mathrm{C}$

The time dependence of the weight change of PCA was generally similar to that previously found for type 316 stainless steel (see Fig. 1); the rate of weight loss decreased with time until a steady state or linear dependence on time was reached. Once this steady state has been attained, the dissolution rate of a particular specimen is obtained from the slope of the weight loss versus time curve. When this was done for the data at 600 and $570^{\circ} \mathrm{C}$, the dissolution rates noted in Table 2 were obtained. Note that, as with the long-term weight losses, the dissolution rate of PCA-A1 at $600^{\circ} \mathrm{C}$ is greater than that of $\mathrm{PCA}-\mathrm{A} 3$ and both have higher dissolution rates than type 316 stainless steel (aIthough the $A 3$ dissolu$t i o n$ rate is not much greater). At $570^{\circ} \mathrm{C}$, the dissolution rates for $A 1$ and $A 3$ are the same and are about $40 \%$ greater than that for type 316 stainiess steel. This result for the $570^{\circ} \mathrm{C}$ specimen is in contrast to the overall weight losses which, as reported above, are comparable for both compositions.
Table 2. Steady-state dissolution rates for PCA and type 316 stainless steel exposed to thermally convected lithium

\begin{tabular}{|c|c|c|c|}
\hline \multirow{2}{*}{$\stackrel{T}{\left({ }^{\circ} \mathrm{C}\right)}$} & \multicolumn{3}{|c|}{$\begin{array}{c}\text { Steady-state dissolution rate } \\
\left(\mathrm{mg} / \mathrm{m}^{2} \cdot \mathrm{h}\right)\end{array}$} \\
\hline & PCA $-A 1 b$ & PCA-A3C & type 31655 \\
\hline $\begin{array}{l}600 \\
570\end{array}$ & $\begin{array}{l}20.8 \\
12.3\end{array}$ & $\begin{array}{l}15.7 \\
12.1\end{array}$ & $\begin{array}{r}13.6 \\
8.5\end{array}$ \\
\hline
\end{tabular}

aslope of wight loss versus time curves after linear dependence was established.

bAnnealed

cCold worked

Metallographic examination of polishrd cross sections of the PCA specimens revealed corrosive attack consistent with the dissolution rate measurements. As shown by the optical micrographs in Fig. 2 and the data in Table 3, the PCA-AI specimen exposed at $600^{\circ} \mathrm{C}$ was attacked (as revealed by the depth of porosity) to a greater extent than the PCA-A3 material exposed at the same temperature. At $570^{\circ} \mathrm{C}$, both $\mathrm{Al}$ and $\mathrm{A} 3$ had similar depths of porosity. The depths of the porous layers on the PCA specimens wera greater than those for similarly exposed type 316 stainless steel.

Table 3. Average depth of corrosive attack of PCA and type 316 stainless steel exposed to thermal]y convected lithium

\begin{tabular}{llll}
\hline \multirow{3}{*}{$\left({ }^{\circ} \mathrm{C}\right)$} & \multicolumn{3}{c}{$\begin{array}{c}\text { Depth of Porositya } \\
(\mu \mathrm{m})\end{array}$} \\
\cline { 2 - 4 } & PCA-A1b & PCA-A3b & type 316 SSC \\
\hline $600^{d}$ & $91 \pm 3$ & $68 \pm 6$ & $52 \pm 4$ \\
570 & $54 \pm 4$ & $51 \pm 2$ & $41 \pm 4$
\end{tabular}

a Average of twenty measurements across both sides of specimen coupons.

$b_{6700} h$ of Jithium exposure

$c 7500 \mathrm{~h}$ of lithium exposure 


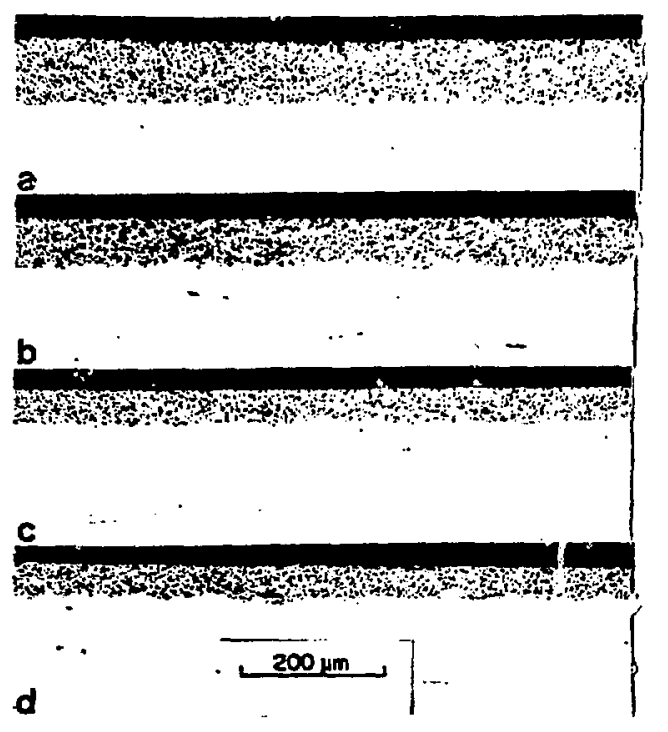

FIGURE 2

Polished cross sections of PCA exposed to thermaliy convective lithium for $6700 \mathrm{~h}$.
(a) $\mathrm{Al}, 600^{\circ} \mathrm{C}$
(d) $A 3,570^{\circ} \mathrm{C}$
(b) $\mathrm{A3}, 600^{\circ} \mathrm{C}$. (c) $\mathrm{Al}, 570^{\circ} \mathrm{C}$.

Scanning electron microscopy and associated energy dispersive $x$-ray analysis of the PCA specimens exposed at $600^{\circ} \mathrm{C}$ showed that $\mathrm{Al}$ and A3 had similar porous surface morphologies layers (see Fig. 3). Energy dispersive $x$-ray spectra taken from these surfaces revealed significant depletion in nickel and chromium.

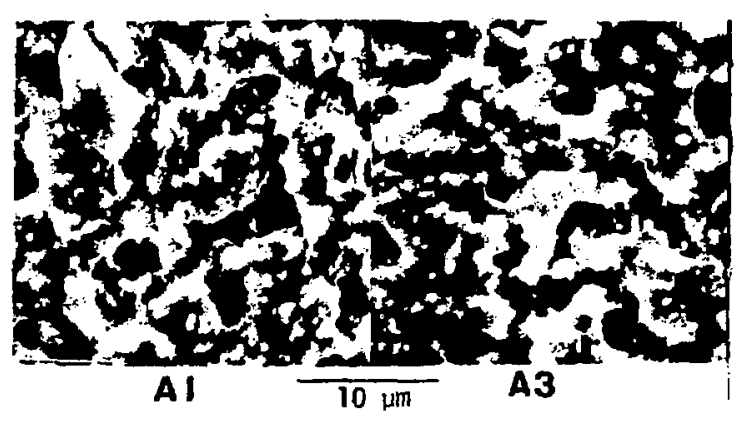

FIGURE 3

Scanning electron micrographs of PCA exposed to thermally convective lithium for $6700 \mathrm{~h}$ at $600^{\circ} \mathrm{C}$
Analyses of a selected number of the nodules observed on these surfaces showed them to be enriched in molybdenum or titanium relative to the surrounding matrix.

\section{DISCUSSION}

In general, the characteristics of the corrosion of PCA in flowing lithium, in terms of the dissolution behayior with time and the effects of exposure on the surface morphology and composition, are very similar to what is observed when standard austenitic alloys are exposed under similar conditions. For example, as already mentioned in the Results section and as seen in Fig. 1, the weight losses of PCA follow a similar time dependence as that of type 316 stainless steel.2,3 This is to be expected for $\mathrm{Fe}-\mathrm{Ni}-\mathrm{Cr}$ alloys since it is thought that the higher, initial rates of weight losses correspond to the rapid preferential leaching of nickel and chromium while the final steady-state rate is characteristic of the dissolution of the corrosion-modified surface layer. 2 It is thus not surprising that an alloy with a composition like that of PCA exhibits this type of behavior. Furthermore, the porosity that developed when PCA was exposed to flowing lithium (Fig. 3 ) is very similar to that abserved on type 316 stainless steel and higher nickel alloys.2,4,6,7 Finaliy, the reported depletion of nickel and chromium from PCA is also characteristic of the $\mathrm{Fe}-\mathrm{Ni}-\mathrm{Cr}$ class of alroys. 4,6

While it is apparent from the above discussion 1 that the corrosion reactions between flowing lithium and PCA are the same as those that occur in other lithium-nickelbearing alloy systems, the extent of these reactions are not necessarily similar. For example, as measured by dissolution rates and depth of attack, the corrosion of PCA is greater than that of type 316 stainiess steel. 
Because of the role of nickel in the dissolution process, this greater susceptibility of PCA relative to type 316 stainless steel can be attributed to the higher nickel content of PCA. Indeed, prior work has shown that the mass transfer of $\mathrm{Fe}-\mathrm{Ni}-\mathrm{Cr}$ alloys in thermally convective lithium increased as the concentration of nickel was increased from 11 to $32 \mathrm{wt} \% .6$ Furthermore, a recent study of PCA exposed in a lithium forced convection loop system yielded similar results on the accelerated corrosion of this alloy with respect to typical austenitic stainless steel. 7 It is interesting to note that this compositional dependence is also observed in another liquid metal system: PCA suffered greater corrosion than type 316 stainless steel in $\mathrm{Pb}-17$ at. $\%$ Li. 8

The above data show that for long time exposures the corrosion of the annealed PCA specimen at $600^{\circ} \mathrm{C}$ was greater than that of the cold worked specimen exposed at this temperature, while, at $570^{\circ} \mathrm{C}$, no difference was observed. The reason for the greater corrosion of the annealed material at $600^{\circ} \mathrm{C}$ is not apparent, particularly since other work has shown the opposite effect. 7 However, these other experiments were not only conducted at lower temperatures but were also for shorter exposure times than the present study, wich for short times showed slightly greater wetght losses for the cold worked specimens. A possible explanation for the greater corrosion of the annealed material in this study may have to do with the respective starting grain sizes of $A 1$ and $A 3$. If the corrosion process is initiated by localized reactions at grain boundaries, 6 the smaller grain size of Al may lead to greater attack due to the higher density of grain boundaries exposed to the lithium. At lower temperatures (1ike those of the work reported in ref. 7), another reaction may control the overall corrosion process such that the cold worked material is corroded more rapidiy. In this regard, it is interesting to note that the present results show an effect at $600^{\circ} \mathrm{C}$ but not at $570^{\circ} \mathrm{C}$.

The observation of molybdenum enriched nodules on lithium dissolved surfaces has also been reported previousiy for type 316 stainless stee1.6 These features are thought to result from the resistance of molybdenum to dissolution in lithium such that the nodules are areas of molybdenum precipitates for residual molybdenum since its carbide is unstable in lithium) that recede more slowly than the surrounding matrix. This same type of behavior probably explains the new observation of a titaniumenriched feature. Titanium is useu in PCA as a carbide former and such titanium-containing nodules probably represent sites of this carbide (which is stable in lithium).

\section{SUMMARY}

The exposure of an austenitic alloy composed of $65.0 \mathrm{Fe}-15.9 \mathrm{Ni}-13.0 \mathrm{Cr}-1.9 \mathrm{Mo}-1.9 \mathrm{Mn}-$ $1.7 \mathrm{Si}-0.5 \mathrm{Ti}-0.05 \mathrm{C}$ (wt $x$ ) to thermaliy convective lithium for $6700 \mathrm{~h}$ at 600 and $570^{\circ} \mathrm{C}$ resulted in corrosion reactions that were similar to what is observed for other austenitic alloys exposed under similar conditions: preferential depletion of nickel and chromium, porosity development, surface nodules, and constant dissolution rates at long times. However, when compared to baseline data of type 316 stainless steel, this PCA alloy was corroded more rapidly due to its higher concentration of nickel. The solution-annealed PCA corroded more than cold worked PCA at $600^{\circ} \mathrm{C}$ but both forms of this alloy showed similar corrosion rates at $570^{\circ} \mathrm{C}$. Such an observation may indicate an influence of grain boundary density on the rate-controlling step for the corrosion process at higher temperatures. 
1..,$+ \cdots$

6. REFERENCES

1. P.J. Maziasz and T.K. Roche, J. Nucl. Mater. 1038104 (1981) 797-802.

2. P.F. Tortorelli and J.H. DeVan, J. Nucl. Mater. 85886 (1979) 289-93.

3. P.F. Tortore11:, J.H. DeVan, and J.E. Selle, Corrosion in lithium-stainless steel thermal-convection systems, in: Proc. 2nd Int '1. Conf. on Liq. Metal Technol. in Energy Production, CONF-800401-P2, (U.S. Department of Energy, 1980) pp. 13-44-54.

4. P.F. Tortorelli and J.H. DeVan, Effects of a flowing lithium environinent on the surface morphology and composition of dustenitic stainless steel, submitted for publication in Microsturctural Science.

5. G.C. Burrow, M.G. Down, and C. Bagnall, J. Nuci. Mater. 103\$104 (1981) 657-62.

6. P.F. Tortorelli and J.H. DeVan, J. Nucl. Mater. $103 \& 104$ (1981) 633-38.

7. 0.K. Chopra and D.L. Smith, ADIP Semiannual Prog. Rept. DOE/ER-0045/10 (March 31, 1981) $195-200$.

8. 0.K. Chopra and D.L. Smith, Corrosinn of ferrous alloys in eutectic $\mathrm{Pb}-\mathrm{L} i$ envi ronment, this yolume. 


\section{DISCLAIMER}

This report was prepared as an account of work sponsored by an agency of the United States Government. Neither the United States Government nor any agency thereof, nor any of their employees, makes any warranty, express or implied, or assumes any legal liability or responsibility for the accuracy, completeness, or usefulness of any information, apparatus, product, or process disclosed, or represents that its use would not infringe privately owned rights. Reference herein to any specific commercial product, process, or service by trade namc, trademark, manufacturer, or otherwise does not necessarily constitute or imply its endorsement, recommendation, or favoring by the United States Government or any agency thereof. The views and opinions of authors expressed herein do not necessarily state or reflect those of the United States Government or any agency thereof. 